\title{
EUROPEAN AUTOMOTIVE TECHNOLOGICAL INNOVATION SYSTEMS IN THE AGE OF DISRUPTION: THE SUPPLIERS' VIEW
}

\author{
Ana Hafner \\ Faculty of Information Studies, Slovenia \\ E-mail: ana.hafner@fis.unm.si \\ Dolores Modic \\ Nord University Business School, Norway \\ E-mail: dolores.modic@nord.no
}

\begin{abstract}
Although empirical studies show that suppliers' innovativeness enhances original equipment manufacturers' (OEM) total innovation performance, some evidence reveals that suppliers' innovation affects OEM in quantitatively and qualitatively limited ways. This study aims to explore innovation systems of European automobile producers, i.e., OEM. Technological innovation systems (TIS) remain relatively underexplored, but the approach is especially valuable for explaining why and how sustainable and circular innovation develop and spread. We applied a mixed-method approach and conducted patent analyses and interviews with 20 respondents from Slovenia, Austria, and Hungary, which are representatives of suppliers for the automotive industry and automotive clusters. We confirm that the European OEMs build innovation ecosystems that are more closed than their Asian counterparts. Furthermore, we define three paths of how inventions of suppliers can reach the OEMs, with developmental suppliers (large companies) having the highest probability of influencing the innovation activity of OEMs. The entry of small and medium-sized enterprises (SME) and start-ups with their inventions is difficult. However, it is not impossible, especially if they develop new solutions connected to current disruptive trends in the automotive industry: electric cars, autonomous driving and digitalisation.
\end{abstract}

Keywords: European automotive industry, suppliers' innovation, technological innovation systems, patents, supply chains, disruptive innovation, OEMs' ecosystem

\section{Introduction}


Supplier innovativeness enhances original equipment manufacturers' (OEM) total innovation performance and is an essential source of both product and process innovations (Azadegan and Dooley 2010; Noordhoff et al. 2011; Oke et al. 2013). Firms must continuously innovate to remain competitive; although suppliers are frequently recognized as a source of innovation for OEMs (Kurpjuweit et al. 2019), a lack of knowledge about the coordination of innovation across firms in the supply chain (Bouncken 2015) and how suppliers are motivated or can be stimulated to innovate (Pihlajamaa et al. 2019) remains. The challenges addressing the cooperation in innovation are not only recognised by the individual companies and experts but implicitly also by the European Union grand strategies, such as Europe 2020 (Rončević 2019).

The network of suppliers concentrated around particular OEMs can also be observed as a technological innovation system (Wieczorek et al. 2015; Suurs and Hekkert 2009; Bergek et al. 2007, 2008; Carlsson 1997; Carlsson and Stankiewicz 1991) in which each connected entity has its specific role in this system that contributes to the final innovative product or service. The technological innovation system presents a system concept developed for a technology-specific perspective on innovation processes (Markard and Truffer 2008; Phirouzabadi et al. 2020). It is an a-spatial innovation concept (Ter Wal and Boschma 2011), which can be embedded in regional, national, or supranational innovation systems. To understand such an innovation system, it is important first to understand what were the key historical shifts in shaping the current suppliers' ecosystem, as well as to understand how the automotive supply chain is organized.

Historically, the automotive industry has not only been one of the leaders in technological innovation but also in innovation in production processes and management. First with Fordism, and later through Post-Fordism and Toyotism (Turi et al. 2015; Dekier 2012), an increasing understanding of suppliers as partners emerged and the focus also shifted to supply chains. Firms are increasingly organized into supply chains to increase value at decreased cost (Bouncken 2015) in several industries, including automotive, which is one of the most important industries in several developed countries. The automotive supply chain is, with over 20,000 parts in a single vehicle that are sourced from thousands of suppliers globally, one of the most complex supply chains in the world (Kern and Wolff 2019, 4).

Supplier innovation occurs when a supplier produces a novel and useful product, process, or service to a downstream buying organization (OEM) (Tingting et al. 2018). Studies show that due to the ongoing trend of outsourcing and shorter innovation cycles, the importance of using suppliers 
as a source of innovation has increased (Winter and Lasch 2016). Furthermore, along with digital transformation, which has become a high priority on leadership agendas (Cepoi 2019) and affects many industries, including the automotive industry (Winkelhake 2019), a new transformation of the automotive industry is on the horizon also due to other disruptive technological trends (Gao et al. 2016; Wittmann 2017). Kern and Wolff (2019, 4) claim that major technology-driven trends such as autonomous driving, electrification, car connectivity and multimodality are predicted to lead to the most significant transformation of the industry since the invention of the car in 1885. Therefore, more studies that will contribute to understanding the innovation process within the automotive supply chain and interactions between suppliers and OEMs, which can lead to new product or process innovations, are needed. Understanding and possible improvement of this innovation process can also lead from disruptive to more sustainable innovation.

There are indications that entities in the supply chain are today increasingly interconnected and interdependent, so some argue that we can no longer speak about the 'supply chain', but rather about an 'ecosystem' (see Sloane and O'Reilly 2013). Within such an ecosystem, several types or tiers of suppliers with interconnecting relationships appear. However, there is a gap in our knowledge about the relationships inside these particular ecosystems in relation to the generation of innovation. Hence, we enrich our present knowledge on technological innovation systems, contributing towards multiscalar conceptualizations of innovation systems (van Lacker et al. 2016), and their horizontal and vertical integrations.

This paper aims to explore the possibilities of automotive suppliers to cooperate in the innovation of multinational automotive producers (OEMs). The study is placed in a particular socio-historical context: the age of disruption and the European innovation system, in particular within the innovation systems of semi-peripheral European countries (Adam et al. 2005). Qualitative research approach (in-depth interviews with semistructured questionnaires) is combined with a quantitative approach, i.e., a patent analysis. The sample of the qualitative study includes different tier suppliers from Slovenia, Austria, and Hungary as well as other business entities who are innovative in the automotive field but are not a part of OEMs' ecosystems.

We show that the European automotive supplier innovation is constrained by the rigidness of the systems, but also that automotive suppliers have three different innovation paths. We also point out that the demand-pull innovation is more prevalent within the OEMs' ecosystems and discover some additional 
attributes of European automotive innovation systems, especially in connection to the relationships between actors when creating and absorbing the automotive innovations.

\section{Problem Formulation - Background and Theory}

Henry Ford was the first to introduce a conveyor belt assembly line (in the early $20^{\text {th }}$ century) and thus ensured cheaper mass production, which enabled cheaper products and thus also mass consumption and higher wages for employees. This concept, which has also been adopted by other industries, is called 'Fordism'. After more than half a century of dominance, while shifts and changes in the market have begun to challenge this concept in both car manufacturing and the global economy, Post-Fordism emerged. Compared to Ford's demand 'push' system, Post-Fordism relied on the opposite principle of 'pull', a system that adapts to customer orders, needs, and requirements. The principle of the supply chain is also different, which was another significant change brought about by Post-Fordism, which involves individual specialized companies as suppliers to the car manufacturer. This change meant that OEMs no longer manufactured all the necessary components themselves, but hired appropriate subcontractors or suppliers, while OEMs focused mainly on activities at the end of the production chain (Turi et al. 2015).

The next shift was Toyota's production system (TPS or Toyotism), developed by Taiichi Ohno and Eiji Toyoda between 1948 and 1975. In essence, Fordism and Post-Fordism emphasize production principles and supply chain design, while Toyotism focuses primarily on the organizational culture aspect and its importance for the competitiveness of the OEM. Another interesting change within Toyotism was that suppliers were no longer seen as 'suppliers' but as 'partners', which meant a whole new level of trust and mutual respect between the various links in the supply chain that would also be seen in productivity of OEM and supply chain efficiency (Turi et al. 2015).

Until 1973, other companies in the US and Japan showed little interest in TPS, until the need to reduce production cost arose. Since then, the success that Toyota has achieved has received much attention, and there has been great interest in its management concept (Dekier 2012). Thus the nurturing of the supplier chains, also concerning their innovation potential, began.

Today, the transformation of the automotive industry is exacerbated by disruptive technological trends (Gao et al. 2016; Wittmann 2017; Winkelhake 2019; Lazard and Ronald Berger 2019; Kern and Wolff 2019), which can also 
cause significant changes in supply chain structure, i.e., the stability of the automotive ecosystem and the relationships within it.

Figure 1: Automotive supply chain or ecosystem

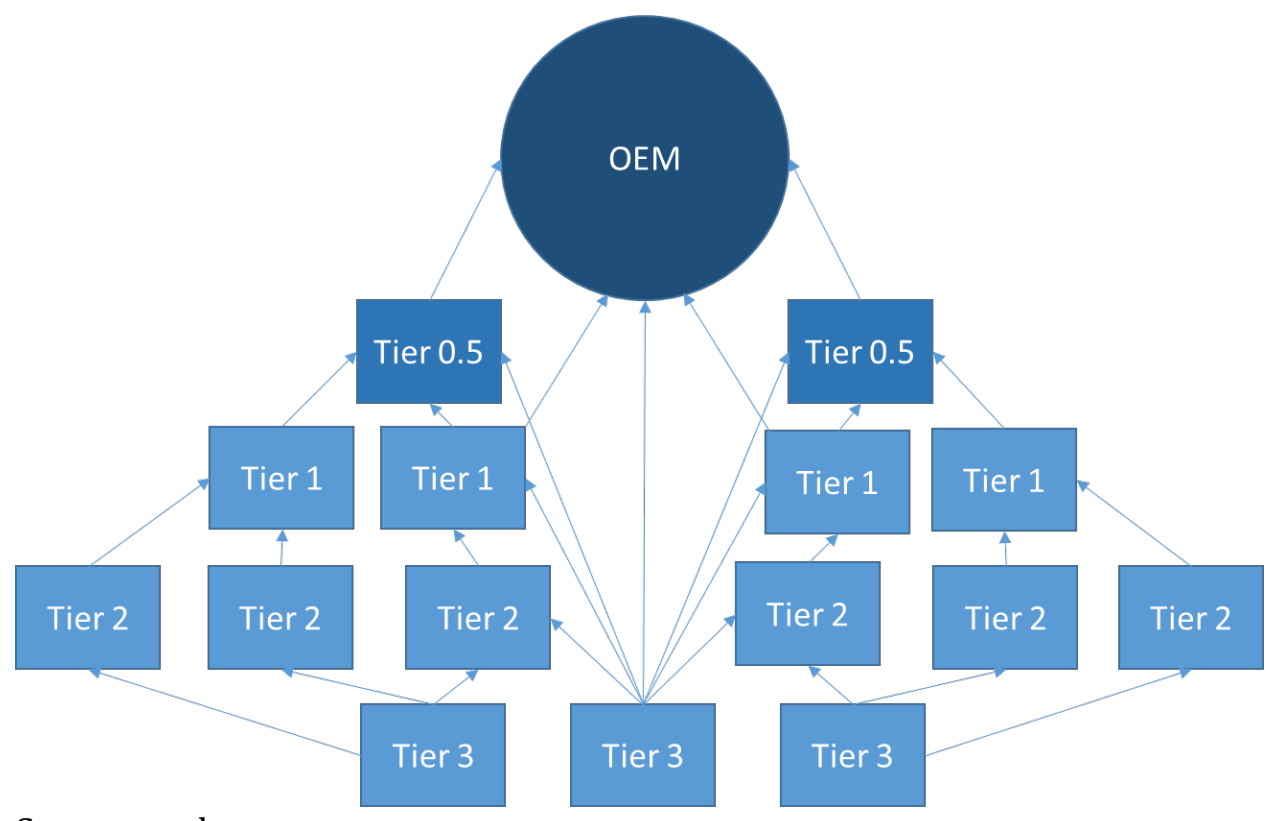

Source: authors

The OEM's ecosystem consists of a hierarchical network of suppliers. Traditionally, first-tier (Tier 1) suppliers are direct suppliers of vehicle components to OEM; second-tier (Tier 2) suppliers are suppliers to Tier 1, and third-tier (Tier 3) suppliers supply raw materials to Tier 1, Tier 2 or OEM. Over time, due to the expansion of automotive markets in Europe and the US, some of the first-tier suppliers evolved into so-called mega-suppliers (Tier 0.5 ), taking over full design and market research and logistical integration of comprehensive modules for OEMs (Wang 2014; Volgina 2011).

According to Carlsson and Stankiewicz (1991: 93), a technological innovation system (TIS) is defined as a 'dynamic network of agents interacting in a specific economic/industrial area under a particular institutional infrastructure and involved in the generation, diffusion, and utilization of technology'. Technological innovation systems remain relatively underexplored, but the approach is especially valuable for explaining why and how sustainable technologies develop and diffuse (Bergek et al. 2007). 
Furthermore, Bergek et al. (2008) point out the need to make several choices regarding the technological innovation system studied in the present paper: regarding the focusing device (product orientation vs focusing on a particular knowledge field); breadth versus depth orientation; and the spatial domain.

Firstly, in regard to the focusing device of TIS, instead of focusing on a particular product, we focus on a particular knowledge field (Bergek et al. 2008). There are two reasons for this. Firstly, whilst the traditional notions of innovation systems focused mainly on geographical proximity, newer conceptualizations, such as that of technological innovation systems, now focus more on collective learning. In the automotive sector, the increasing emphasis on supplier chains of OEM and the rise of so-called mega suppliers - both increasing the potential for collective learning - lead to the emergence of (innovation) ecosystems. In line with this, many scholars turned their attention to the phenomenon of the network of actors involved in developing and in commercializing innovations (de Vasconcelos Gomes 2011), their interdependence, as well as the non-redundant knowledge they bring into the innovation ecosystem.

Secondly, we define the breadth of the study. We focus on the suppliers' innovations in the automotive sector. We do so, as our understanding of the system dynamics of the innovation systems, as well as technological systems, remains limited. The usual approach to studying innovation systems is from an aggregated perspective of, for example, a national innovation system; thus the investigations are performed as if these would be relatively static phenomena (Suurs and Hekkert 2009). At present, there is a lack of studies in newly emerging fields, and consequently emerging (technological) innovation systems, but which can still be influenced to a higher degree (Collingridge 1980, Suurs and Hekkert 2009). The paradigmatic changes inside the industry (Lazard and Roland Berger 2019) warrant a particular focus on automotive innovations by suppliers. This technological innovation system is an emerging one, similar to, for example, the Swedish TIS for biocomposites, but from the industry and from the policy perspective (Bergek et al. 2008, 412) in would make sense to 'work towards integrating these into one overall TIS, since this may increase learning, knowledge development and, thereby, the rate of development of the system as a whole'.

Thirdly, the researched TIS might have a spatial focus, such as ours. In terms of actors (entities) or agents of TIS, we focus on the suppliers, especially from Slovenia, as well as Hungary and Austria, which are embedded in peripheral and semi-peripheral parts of Europe. The specific focus entities are thus Slovenian, Hungarian and Austrian Tier 1 and Tier 2 suppliers, depending mostly on German (but also French and Italian) automotive OEMs. 
Our focus on the collective learning, i.e., innovation creation and absorption, is contributing to enriching and mitigating the problem of the spatial conceptualization of the innovation systems (Oinas and Malecki 2002; Rutten and Boekema 2007). We need to take into account that TIS, as (non-state) fields, are thus embedded in a complex web of other fields (Fligstein and McAdam 2012); vertically with national and macro-regional innovation systems; and a horizontally, with other proximate fields such as sectorial innovation systems. In our case, these are the macro-regional innovation system of European semi-peripheral countries, and the sectorial automotive innovation system.

The automotive innovation ecosystems involving automotive suppliers and their relationships are thus an interesting and relevant manifestation of an innovation technological system; as the influence of the OEM and megasuppliers is increasingly strengthening, the institutional infrastructure also changes in the field of generating innovations and their absorption into the OEM. Furthermore, the new paradigmatic changes inside the industry are shifting the focus towards more sustainability.

As mentioned above, the dynamics of this system are an interesting issue. Kurpjuweit et al. (2018) distinguish between suppliers' push and pull innovations. Innovations initiated by OEM (pull innovations) are often customized to the needs of the OEM, offer limited market opportunities for suppliers, and tend to produce increased dependency on the OEM. For this reason, suppliers engage in an innovation push strategy, developing new products on their own and pushing them to OEM at some stage of the development process. Innovation push can mitigate the disadvantages of innovation pull while allowing suppliers to access the innovation competencies of OEM and strengthening the supplier's relationship with OEM. Their study showed that supplier innovation push could be a viable alternative to the innovation pull approach, which is currently the standard practice in most industries; however, OEMs also raised concerns about the push behaviour of some suppliers: they complained that suppliers offered innovations that did not fit their needs, they were vague about the potential of the innovations offered, suppliers also proposed solutions for problems that did not even exist. By analysing examples, researchers identified factors that should shape suppliers' decisions about the timing and target of innovation push efforts. Therefore, the right timing and the choice of OEM to push have a substantial impact on a pushed innovation's chances of success. Their study of 15 respondents ( 7 OEMs, 6 suppliers and 2 consulting firms) is not limited to the automotive industry, although five respondents came from this sector. Our study continues their work with the difference that we did not 
include any OEM in our research sample, so the results are based only on the suppliers' view. Furthermore, we want to identify how a position in the supply chain influences the ability of suppliers to innovate.

We focus on the following research questions. Firstly, we focus on the scope of the cooperation of the automotive industry suppliers with their customers (i.e., the car manufacturers (OEM)). We focus on how the suppliers cooperate with them, and which channels are at their disposal. Secondly, we focus on the issue of the suppliers' pull or push innovations (i.e., who determines what to invent: supplier (push innovation) or OEM (pull innovation)); this allows us to understand what possibilities suppliers have in the development of their inventions and how much they have to adapt to the OEM's requirements. Thirdly, we distinguish between the suppliers' product and process innovations and their possible connections with the hierarchical position of the supplier in the supply chain. We are also interested in the automotive ecosystem 'outsiders' (entities not included in the system) which, however, invent in the field of automotive components: what possibilities do they have to penetrate in the OEM's ecosystem?

Our propositions are:

1) The innovation of European automotive suppliers is more pull- than push-driven.

2) Tier 1 suppliers may also push innovation and are more likely to innovate in the product field than Tier 2 suppliers.

3) Business entities which are not included in the supply chain (i.e., outsiders) have very little chance of pushing innovation to OEM, and their technology transfer channels are more likely to be incidental than planned.

\section{Methodology}

The study ${ }^{3}$ started in the second half of 2017, with in-depth interviews conducted in the second half of 2018 in Slovenia, and in 2019 extended to two neighbouring countries, Austria and Hungary.

We performed a patent analysis using the database of European Patent Office PATSTAT, 2019 spring edition. We examine the patenting activity of the top 20 automotive patent holders in the last ten years, from Europe and Asia, and compare their joint patenting activity as a proxy for their openness to

3 The study has been supported by European Union, ERDF, and Republic of Slovenia, Ministry of Education, Science and Sport (Operation No. C3330-17-529006 $»$ Researchers-2.0-FIŠ-529006«). 
absorb outside innovation. To determine patented inventions belonging to the automotive industry, we used the categories of International Patent Classification (IPC) codes proposed by the European Patent Office, which performs annual statistics for the European Automobile Manufacturers Association ACEA (ACEA 2019, 68): B60: Vehicles in general; B62: Land vehicles for travelling otherwise than on rail; F02: Combustion engines; hotgas or combustion-product engine plants; and F16: Engineering elements or units; general measures for producing and maintaining effective functioning of machines or installations; thermal insulation in general.

In Slovenia, we conducted semi-structured interviews with representatives of selected 16 units from the automotive industry (or scientists and inventors in the field of new solutions for the automotive industry). In the case of SMEs, our respondents were mostly directors, while in large companies, they were the heads of $R \& D$ departments. The interviews lasted approximately 45 minutes.

Two smaller and three large Slovenian companies were selected according to a larger number of patents, one large one due to successful business, two smaller companies were spin-off companies of public research organizations, and four were selected due to the technological importance of their current inventions. We also decided to conduct interviews with two representatives of the supportive environment: in the first case, this is a business association, and in the second a technology transfer office. In the following year, we supplemented this sample with four chosen Austrian and Hungarian respondents, three of them are automobile suppliers, and one is a business association. Therefore, our participants are very diverse, but such a sample was intentionally chosen because we wanted to cover as many different aspects of the entities, active in the field of automotive inventions, as possible. 
Figure 2: Respondents placed within OEMs' innovation ecosystems

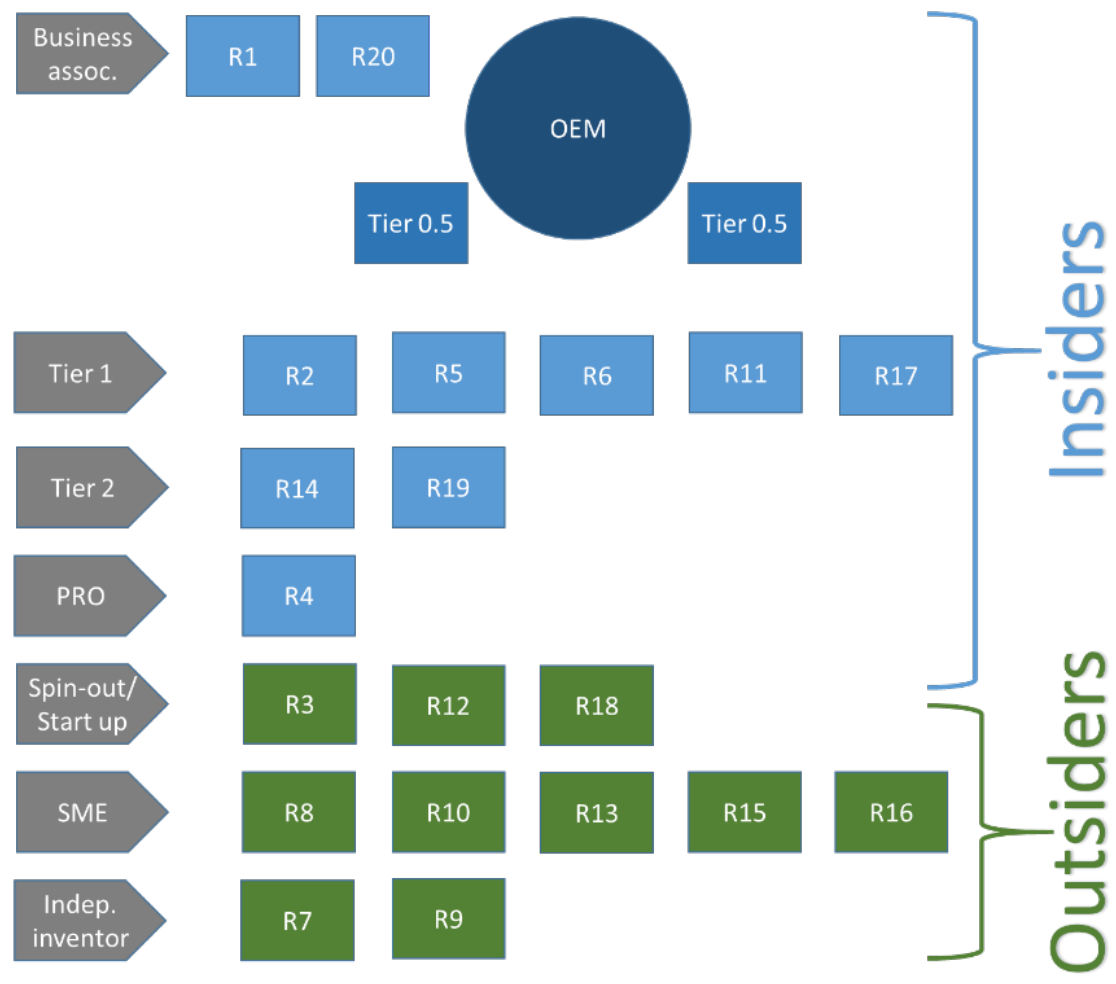

Source: authors

Respondents that are integrated into the OEMs' innovation ecosystems may be called 'Insiders' while the respondents who are (successfully or unsuccessfully) trying to push their inventions into the system are 'Outsiders'.

With the exception of two business associations (Slovenian and Hungarian automotive cluster), all respondents are patent owners. Table 1 (in the appendix) shows the approximate number of patents for each respondent. We have taken into account patent families based on the Espacenet database (May 2020). We took the total number of all patents of a given entity; although not all of them correspond to the automotive industry, most do. In the criteria for determining the size of the company, we took into account the definition of the European Commission (2020). 


\section{Problem Solution - Results}

\subsection{Results of the preliminary quantitative study}

Since our focus is on the European automotive industry and the role of suppliers' innovations in Europe, we first look into whether or not the most innovative (based on their patenting activity) European OEMs or Tier 0.5 suppliers are open to seeking innovation from outside. These innovative companies are important actors of the technological innovation systems in the automotive sector.

We analysed the PATSTAT patent database data, focusing on the patenting and joint patenting activity of the top 20 automotive patent holders in the world in the last 10 years.

We discovered that Asian OEMs are more inclined to cooperate (with other companies and universities) than European and American (Table 2). While European and US patent owners are engaged in an average in 13.5\% of joint patents, the average share of joint patenting by their Asian competitors is $43.4 \%$.

Table 2: Top 20 world patent holders in the automotive industry

\begin{tabular}{|c|c|c|c|c|c|c|}
\hline & Company & Country & $\begin{array}{l}\text { Automotive } \\
\text { patent } \\
\text { applications } \\
\text { (last } \\
\text { years) }\end{array}$ & $\begin{array}{l}\text { All patent } \\
\text { applications } \\
\text { between } \\
2010 \text { and } \\
2019 \text { }\end{array}$ & $\begin{array}{l}\text { Number of } \\
\text { joint patent } \\
\text { applications } \\
(2010 \\
2019)\end{array}$ & $\begin{array}{l}\% \text { of joint } \\
\text { patent } \\
\text { applications }\end{array}$ \\
\hline 1 & TOYOTA & Japan & 55157 & 91427 & 32641 & 36 \\
\hline 2 & ROBERT BOSCH & Germany & 40346 & 75492 & 13257 & 18 \\
\hline 3 & $\begin{array}{lr}\text { HONDA } & \text { MOTOR } \\
\text { COMPANY } & \end{array}$ & Japan & 32759 & 46374 & 11476 & 25 \\
\hline 4 & $\begin{array}{l}\text { FORD GLOBAL } \\
\text { TECHNOLOGIES }\end{array}$ & USA & 28870 & 45540 & 4502 & 10 \\
\hline 5 & $\begin{array}{l}\text { HYUNDAI MOTOR } \\
\text { COMPANY }\end{array}$ & $\begin{array}{l}\text { South } \\
\text { Korea }\end{array}$ & 27985 & 63526 & 16472 & 26 \\
\hline 6 & $\begin{array}{l}\text { GM GLOBAL } \\
\text { TECHNOLOGY } \\
\text { OPERATIONS }\end{array}$ & USA & 24636 & 30388 & 5038 & 17 \\
\hline 7 & $\begin{array}{l}\text { SCHAEFFLER } \\
\text { TECHNOLOGIES \& } \\
\text { COMPANY }\end{array}$ & Germany & 22639 & 24453 & 2454 & 10 \\
\hline 8 & $\begin{array}{l}\text { DENSO } \\
\text { CORPORATION }\end{array}$ & Japan & 21751 & 22727 & 13110 & 58 \\
\hline 9 & DAIMLER & Germany & 14776 & 19710 & 1822 & 9 \\
\hline 10 & $\begin{array}{ll}\text { NISSAN } & \text { MOTOR } \\
\text { COMPANY }\end{array}$ & Japan & 13427 & 18030 & 6884 & 38 \\
\hline
\end{tabular}




\begin{tabular}{|c|c|c|c|c|c|c|}
\hline 11 & $\begin{array}{l}\text { GE (GENERAL } \\
\text { ELECTRIC } \\
\text { COMPANY) }\end{array}$ & USA & 13286 & 47325 & 10525 & 22 \\
\hline 12 & $\begin{array}{l}\text { ZAHNRADFABRIK } \\
\text { FRIEDRICHSHAFEN }\end{array}$ & Germany & 13274 & 12987 & 1565 & 12 \\
\hline 13 & $\begin{array}{l}\text { PEUGEOT CITROEN } \\
\text { AUTOMOBILES }\end{array}$ & France & 11701 & 10010 & 1322 & 13 \\
\hline 14 & $\begin{array}{l}\text { BMW (BAYERISCHE } \\
\text { MOTOREN WERKE) }\end{array}$ & Germany & 11690 & 16146 & 1404 & 9 \\
\hline 15 & $\begin{array}{l}\text { TOYOTA MOTOR } \\
\text { CORPORATION }^{4}\end{array}$ & Japan & 11407 & $\mathrm{n} / \mathrm{a}$ & $\mathrm{n} / \mathrm{a}$ & $\mathrm{n} / \mathrm{a}$ \\
\hline 16 & $\begin{array}{l}\text { BRIDGESTONE } \\
\text { CORPORATION }\end{array}$ & Japan & 10623 & 13585 & 3208 & 24 \\
\hline 17 & AUDI & Germany & 10503 & 15902 & 1932 & 12 \\
\hline 18 & VOLKSWAGEN & Germany & 10417 & 12280 & 1824 & 15 \\
\hline 19 & $\begin{array}{l}\text { KIA MOTORS } \\
\text { CORPORATION }\end{array}$ & $\begin{array}{l}\text { South } \\
\text { Korea }\end{array}$ & 8925 & 11625 & 11238 & 97 \\
\hline 20 & RENAULT & France & 8774 & 8978 & 1349 & 15 \\
\hline
\end{tabular}

Source: authors' analysis based on PATSTAT 2019

Our results are in line with the earlier, but narrower, study by Hertenstein and Williamson (2018) who compared German and China OEMs and Tier 1 suppliers. They similarly show that the two countries have different approaches in OEM-supplier relationships: Germans have a more in-house driven approach to development with close interaction with suppliers over a long cycle, while Chinese are more open to externally available technologies what opens up the potential for them to bring disruptive competition to the global automotive industry, especially in emerging markets. Therefore, based on our analysis and the conclusions of Herstenstein and Williamson (2018) we conclude that the European automotive innovation systems seem to be more rigid and less prone to jointly innovating than its Asian counterparts.

\subsection{Results of the qualitative study}

Our research shows that there is a significant difference between established suppliers which are well integrated into the supply chain (insiders of OEM's ecosystem) and potential newcomers (outsiders). In our sample, R2, R5, R6, R11 and R17 are large companies, Tier 1 suppliers that communicate directly with OEM or in some cases (for some products) through Tier 0.5 suppliers. Most of them have the status of so-called 'developmental supplier'. The development of new car components is entrusted to suppliers, but the OEM

${ }^{4}$ Toyota Motor Corporation appears in the database also as トヨタ 自動車株式会社. 
gives clear guidelines of what they want to have and how much space there is for this solution in the car.

R11: 'Customer (OEM) prepare a quality technical basis of what they want to have, in a sense, here must be something, we are not interested in what this is, it is important that it is at a good price and that it satisfies the function.'

R2: "The car is designed at the highest (OEM) level. We get the shapes, these lines, surfaces, and we have to squeeze our solution into that by satisfying the legal regulations as well. What's inside is our own invention. So you are limited by space and exterior design, but the solution is your own. However, when we find the solution, a lot of negotiation with customers (OEM/ Tier 0.5) follows.'

After the development of a prototype, the supplier is again in contact with the OEM, which can suggest possible adaptations; there are many negotiations, so the final invention is a result of mutual communication and suggestions. This fact is also emphasized by R17 below.

R17: 'Our customers (OEMs) know what they develop and what will be on the market in a couple of years. We are trying to be included in development and have tight relations with customers - this is how we can support them, and they can support us.'

When Tier 1 suppliers develop a new solution, they usually apply for a patent.

R5: 'From a purely industrial point of view, the aim of filing a patent - also because of examination - is to see if the route is safe or not, so maybe the investment may need to be stopped quickly. [...] So the purpose of a patent is to make you feel at least a little safe for all the investments you will make. The other thing is to prevent another company from making the same solution.'

However, can these suppliers develop something completely independently from OEMs and then offer this solution to them (this would therefore be the 'push' innovation)? They can, but the chances of acceptance of this invention are low.

R6: 'We can also give our suggestions. When we were dealing with [field] XXX, we developed this [invention] ZZZ. That was entirely our idea. We made it and offered it to car manufacturers (OEMs). A lot of interest was shown, but then it's all a matter of money. Manufacturers are interested in incorporating the novelty, but only in the case that it will not be more expensive than the solution they already have. They are not willing to pay much for it.'

Public research organisations (PRO), in contrast, mostly cooperate with OEM or Tier 1 suppliers under such agreements that they are engaged in the development of a new solution; however, a patent belongs to a company.

R4: 'We cooperate with companies a lot, but we had for example such cooperation with XXX that we left our intellectual property to them. We also have a very big project together with YYY, but we don't patent together there either. I don't think we have any joint patents yet.' 
Tier 2 suppliers are, in contrast, limited with all inventive proposals. R14: 'It is very hard to come on the position of Tier 1, but not because you don't have knowledge to be in this position but because there is a whole procedure which works under the specific principles and standards where the stability of supply chain structure is the most important; stability in two senses: timely logistics and product quality. [...] Until this moment you work under the system: this is documentation, do this for us. So if the question was: do we only follow their instructions? I believe we have knowledge to do more, but the problem is how to penetrate the system. Small Slovenian companies definitely cannot enter with their inventive proposals.'

Tier 2 suppliers have the possibility of introducing process innovations that are kept as trade secrets. The majority of automotive suppliers' innovation, as R1 believes, actually comes from the field of technological processes.

R1: 'But these innovations are not patented because you will never let a competitor into your production and show him what you have done. These solutions are not visible to the public, and therefore patents are not necessary.' R5: 'If you're a Tier 2 manufacturer, you usually get a drawing from the manufacturer. Then there is the (technological) process, which, however, has the advantage of being a trade secret. [...]. But if you are Tier 1 , where you are the one who enters the market with the product, a patent is necessary.'

Even more limited with suggesting inventive proposals from Tier 2 are small innovative companies and start-ups that simply cannot enter the OEM's ecosystem. For example, R8 has already attempted to connect with larger Slovenian companies and state institutions and describes his experience as follows.

R8: 'I sent this documentation (about invention) to all major companies, but no one even answered me. I was also at the XXX Ministry [...], and they said: we can't help; it's best to sell it abroad.'

Pretty much the same experience is also shared by R7, R13 and R16. They attempted with great effort, however, to make contact with OEMs. They mostly rely on their personal acquaintances.

R10: 'After trying several things, since (OEM) XXX is a reputable company, we finally established a connection with someone who claims he can open the door for us to come to them, since this is the biggest problem (how to come to them) and here we will start.'

For small companies that are not already a part of the supply chain, it is very difficult to make direct contact with OEM. Most OEMs allow the possibility of submitting and describing an inventive proposal through a form on their websites; however, none of our respondents used this option. They prefer to rely on their personal contacts. Start-ups and independent inventors are thus in a relatively unenviable situation in the automotive industry: 
although their inventions may be more breakthrough when compared to those of large companies, they cannot even present them to anyone except a narrow circle of acquaintances. The problem is not the NIH (Not Invented Here) syndrome (e.g., Chesbrough et al. 2014, 41), as a representative of the automotive cluster is convinced.

R1: 'Small companies may have brilliant ideas, but if these are not taken into account in the concept of a car that has already gone through pre-development, development, preparation for production [...] this means that any intervention with a solution brought by someone new means endless changes and costs. [...]. This is the mistake of start-ups: they develop a circle, and they want to push it in every way into something with a square opening.'

However, due to disruptive technology trends and digital transformation, start-ups have more and more opportunities to be noticed by OEMs, especially software companies. Nevertheless, the channels of how they make contact with them seem to be very incidental, as the experience of R18 shows. R18: 'In 2016, we solved a logistic problem with a camera that recognizes different containers. The first prize was to become a supplier and the second prize was to experience driving with different OEM XXX cars. And in this event, we met a guy at Oktoberfest in Munich. And this guy told us: look, you can recognize containers and also food items like chicken, so you can also recognize different surfaces. We said, yes we can do this. So we went to Oktoberfest and XXX bought our software. They said they want to own it, so they paid for the model we created. It is not software-as-a-service; we created software for them; it was a one-time fee.'

R1: 'Start-ups are interesting, especially in the IT field. Big manufacturers are intensively looking for start-ups, not so much for bringing them inventions, OK, for that too but, above all, they want to integrate them into their process and employ them.'

According to the statements of our respondents, we can define three different paths of how suppliers' inventions reach the OEMs:

1) An invention is proposed and designed by OEM: this is usually in the case of Tier 2 suppliers. OEM provides detailed technical documentation of the component they want to implement in a vehicle. A supplier can (or even must) however still invent in the process field: how to make something faster, cheaper and with higher quality than the competition. These innovations are protected as trade secrets.

2) The invention is developed mutually with the OEM and supplier (pull innovation): this is the case of Tier 1 suppliers, which are also developmental suppliers. In this case, the OEM explains the function of a new component and defines a space in a vehicle where the component should fit in. The supplier proposes the final solution and, of course, the OEM has to accept it; therefore, some corrections of the 
solution are frequently needed. That kind of invention has to be patented, and the patent usually belongs to the supplier unless otherwise agreed (which is frequently the case of public research organisations that have contracts under which they undertake development work, but the patent belongs to the client).

3) The invention is proposed and developed by a supplier (push innovation): this is the least common path, but still possible for Tier 1 suppliers and start-ups. OEMs are particularly open to innovations in the field of information and communications technology.

Our findings also confirm our three propositions:

1) The innovation of European automotive suppliers is more pull- than push-driven: OEMs and Tier 0.5 suppliers provide the most inventive proposals. Tier 1 suppliers may be responsible for the development of these proposals, while Tier 2 suppliers only manufacture what is already developed.

2) Tier 1 suppliers may also push innovation and are more likely to innovate in the product field than Tier 2 suppliers: Tier 1 suppliers may communicate directly to OEMs, so they have possibilities to present inventions that they developed independently and, since they are in direct contact, they are also aware of the OEM's needs. Tier 2 suppliers do not have this possibility, and they can thus invent only in the process field.

3) Business entities (SMEs, independent inventors and, in many cases, public research organisations) that are not included in the supply chain do not have much chance of pushing innovation to OEMs. Successful examples of technology transfer, however, do exist, but it seems that this happens rather randomly and rarely. This fact also indicates that the established channels to reach OEMs are predominantly rigid and structured with very limited possibilities for outsiders to enter the system. Such attempts of push innovation should not be mixed with developmental cooperation agreements between OEM and PRO: these agreements are quite frequent, but again, it is the OEM who decides what should be developed and not the PRO.

\section{Discussion}

In recent years, the automotive industry has been facing several challenges, which started before 2020. The COVID-19 pandemic has had fatal consequences for the economy as a whole, and for especially for specific 
industries, such as tourism and the car industry. The changes that led to a decline in the profits of European OEMs in 2019 began some years earlier and are probably connected with what we can call 'disruptive trends' in the automotive industry. According to some authors and research organizations (Lazard and Ronald Berger 2017; McKinsey 2016; Fu et al. 2019), these trends are electrification (and other alternative drives), connectivity (digitization) of vehicles, autonomous driving, and shared mobility. However, connected with electrification and the problem of battery recycling along with other environmental requirements, we can certainly add the circular economy to the group disruptive trends. As one of our respondents (R5) explained, high investment in electrification is especially responsible for the decline of profits before the COVID-19 pandemic. The decline in profits of European OEMs, of course, has also affected suppliers.

Another problem is the uncertain and reckless policy of the European Union: it is not sure when and how the internal combustion-powered cars will be banned, and consumers are finding it increasingly difficult to decide to invest in such a car, while electric cars still have many disadvantages, including a lack of fast-charging infrastructure. This problem has to be solved as it was made - at the policy level - claims one of our respondents (R20). In contrast, all our respondents are convinced that they are well prepared for the transition to electric vehicles that will undoubtedly come.

The decline of profits due to COVID-19 pandemic is visible also now in the Asian OEMs; however, it seems that they cope better with these disruptive trends. China is certainly the world leader in electric drives, but not only because of their air pollution, as one of our respondents (R3) stressed, they own most of the raw materials needed for batteries and electromagnets. There is also another explanation: to adapt to new technological trends, you need to become more open and actively seek innovation outside of your ecosystems. Our quantitative analysis has confirmed that the OEMs pertaining to the European innovation system, and being integral actors of the automotive technological innovation systems, are less inclined to innovate jointly.

So the question is, does willingness to cooperate outside a relatively closed ecosystem (supply chain) also open up the potential for disruptive competition to the global automotive industry? Studies that would confirm this assumption are still lacking; however, Potter and Graham (2019) studied firms in the Toyota supplier association and revealed that supplier electric and hybrid capabilities are associated with a significant increase in the degree of eco-innovation co-patenting. 
Despite that, when we asked our respondents if it would make sense to attempt to connect with Asian manufacturers (who are obviously more prone to external cooperation), large Slovenian companies were against such attempts. Not only because of their loyalty to European OEMs: they also emphasize several obstacles, such as language barriers, different culture, transport costs and inability to compete with competitors there. These elements are related to both the geographical proximity as well as collective learning as building blocks of the innovation system. However, the relative closeness of the European automotive supply is seen as an advantage, and the rigid hierarchy of supply chains is, surprisingly, also not understood as a weakness by our respondents.

Based on our study, we define three different paths of automotive suppliers' innovation: product pull innovation (most frequent for Tier 1 suppliers), process innovation (most frequent for Tier 2 suppliers) and product push innovation (which is possible for Tier 1 suppliers, but also for entities outside OEMs' technological ecosystem, such as start-up companies). Our study does not confirm the findings of Kurpjuweit et al. (2018), who claimed that suppliers could readily engage in an innovation push strategy but only when the timing is right. In the European automotive industry, successful suppliers' push innovations are very rare, and most inventions are developed on the basis of OEMs' requirements; therefore, they are pull innovations. However, suppliers who find new technological solutions according to an OEM's needs may file a patent for this solution independently of the OEM.

\section{Conclusion}

This paper explores the technological innovation system and the relationships between the actors, which are formed in order to create and absorb innovations in the European automotive sector. Thereby, we focus on the innovation potential of the suppliers from the European semi-periphery innovation systems: Slovenian, Austrian, and Hungarian.

The three innovation paths that were have distinguished based on our study reflect a relatively rigid hierarchy of the European automotive supply chains and closed innovation ecosystems in which OEMs and Tier 0.5 suppliers are responsible for the majority of innovation proposals which are later developed by Tier 1 suppliers, while Tier 2 suppliers can innovate only in the process field. Our study confirms that Asian automotive OEMs are more open to external collaboration according to the number of joint patents with other organizations. 
However, since a disruptive transition is on its way, there are indications that European OEMs are becoming more open to outside innovation, especially in the software field. It is still not too late for the European automotive industry to catch up with the rest of the world (specifically Asia) and make the most of this transition; however, the technological ecosystems around European OEMs will probably have to become even more open and susceptible to external innovation. This situation is also a great opportunity for SMEs, start-ups and universities that are developing new solutions in the field of electric vehicles, alternative propulsion systems, connected cars, autonomous vehicles, eco-innovation, the circular economy, and digitalization.

One limitation of this study is its small and very diverse sample of respondents. However, we emphasize that we have reached a point of saturation in terms of new knowledge attained. Nevertheless, we do believe that similar studies would be beneficial if conducted for similar geographies, to allow a common picture of the European automotive TIS as well as sectoral innovation systems to arise. These results could cross-fertilize our knowledge on the regional innovation systems as well as on the European innovation system insofar relating to the innovation-related relationships between suppliers and OEMs, which are present in the majority of important industries.

It is also necessary to emphasize that only a part of the automotive technological innovation system was analysed (i.e., the supply chain) since we do not address innovation and related relationships between OEMs and other actors of the TIS after the production of the final product (car dealers, maintenance and recycling services). These could represent another promising area for further research. In this context, and in light of expanding car electrification, studies on battery recycling innovation should also be a priority. We encourage further research, which would support or reject our assumption about the openness of technological innovation systems and the ability to integrate disruptive innovation.

\section{References}

ACEA. 2019. The Automobile Industry Pocket Guide 2019-2020. https://www.acea.be/uploads/publications/ACEA Pocket Guide 20192020.pdf. Accessed 12.7.2019. 
Adam, Frane, Makarovič, Matej, Rončević, Borut, Tomšič, Matevž. 2005. The challenges of sustained development: the role of socio-cultural factors in EastCentral Europe. New York; Budapest: Central European University Press.

Azadegan, Arash, Dooley, Kevin. 2010. "Supplier innovativeness, organizational learning styles and manufacturer performance: An empirical assessment." Journal of Operations Management 28 (6): 488-505.

Bergek, Anna, Jacobsson, Staffan, Carlsson, Bo, Lindmark Sven, Rickne, Annika. 2008. "Analyzing the functional dynamics of technological innovation systems: A scheme of analysis." Research policy 37 (3): 407-429.

Bergek, Anna, Jacobsson, Staffan, Hekkert, Marko. 2007. Functions in innovation systems: a framework for analysing energy system dynamics and identifying goals for system-building activities by entrepreneurs and policy makers. In: Foxon, T., Kohler, J., Oughton, C. (Eds.), Innovations for a Low Carbon Economy: Economic, Institutional and Management Approaches. Cheltenham: Edward Elgar.

Bouncken, Ricarda B. 2011. "Supply Chain Contingencies: The Effects of UpStream Directives on Supplier's Innovation Performance." Engineering Management Journal 23 (4): 36-46.

Carlsson, Bo (Ed.). 1997. Technological systems and industrial dynamics. Boston, Dordrecht, London: Kluwer Academic Publishers.

Carlsson, Benny, Stankiewicz, Rikard. 1991. "On the nature, function and composition of technological systems." Journal of evolutionary economics 1 (2): 93-118.

Chesbrough, Henry, Vanhaverbeke, Wim, West, Joel. (ed.). 2014. New frontiers in open innovation. Oxford: Oxford University Press.

Cepoi, Victor. 2019. "Reshaping the Danube Region imaginary: a focus on digital transformation and HPC." Research in Social Change 11 (2): 58-78.

Collingridge, David. 1980. The Social Control of Technology. London: Pinter Publishers. 
Dekier, Łukasz. 2012. "The Origins and Evolution of Lean Management System." Journal of International Studies 5 (1): 46-51.

de la Mothe, Johna, Paquet, Gilles (Eds.). 1998. Local and regional systems of innovation. Dordrecht: Kluwer.

de Vasconcelos Gomes, Leonardo Augusto, Figueiredo Facin, Ana Lucia, Salerno, Mario Sergio, Kazuo Ikenami, Rodrigo. 2018. "Unpacking the innovation ecosystem construct: Evolution, gaps and trends." Technological Forecasting and Social Change (136): 30-48.

European Commission. 2020. Internal Market, Industry, Entrepreneurship and SMEs: What is an SME? https://ec.europa.eu/growth/smes/businessfriendly-environment/sme-definition en. Accessed 5. 1. 2020.

Fu, Shanliang, Alex Ng Hou Hong, Kim Yew Lim, Wong Chee Hoo. 2019. The Strategic Elements and Performance of Chinese Publicly Listed Automotive Manufacturers: A Proposed Conceptual Framework. International Conference on Innovation and Technopreneurship 2019. http://eprints.intimal.edu.my/1356/1/vol.2019_056.pdf. Accessed 5. 1. 2020.

Gao, Paul, Kaas, Hans-Werner, Mohr, Detlev, Wee, Dominik. 2016. Disruptive trends that will transform the auto industry. McKinsey \& Company. https://www.mckinsey.com/industries/automotive-and-assembly/ourinsights/disruptive-trends-that-will-transform-the-auto-industry. Accessed 6. 9. 2020.

Hertenstein, Peter, Williamson, Peter. 2018. The role of suppliers in enabling differing innovation strategies of competing multinationals from emerging and advanced economies: German and Chinese automotive firms compared. Technovation. 70-71, 46-58.

Kern, Johannes, Wolff, Pascal. 2019. The digital transformation of the automotive supply chain - an empirical analysis with evidence from Germany and China: Case study contribution to the OECD TIP Digital and Open Innovation project.

https://www.innovationpolicyplatform.org/www.innovationpolicyplatform. org/system/files/imce/AutomotiveSupplyChain GermanyChina TIPDigitalC aseStudy2019 1/index.pdf. Accessed 6. 9. 2020. 
Kurpjuweit, Stefan, Reinerth, Dagmar, Wagner, Stephan M. 2018. "Supplier Innovation Push." Research-Technology Management 61 (2): 47-55.

Lazard and Ronald Berger. 2017. Global Automotive Supplier Study 2018. https://www.rolandberger.com/en/Publications/Global-AutomotiveSupplier-Study-2018.html. Accessed 16. 5. 2019.

Lazard and Roland Berger. 2019. Global Automotive Supplier Study. https://www.lazard.com/media/451032/global-automotive-supplierstudy-2019.pdf. Accessed 9. 8. 2020.

McKinsey \& Company. 2016. Automotive revolution - perspective towards 2030: How the convergence of disruptive technology-driven trends could transform the auto industry. https://www.mckinsey.com/ /media/mckinsey/industries/automotive $\% 2$ 0and\%20assembly/our\%20insights/disruptive $\% 20$ trends\%20that $\% 20$ will \%20transform\%20the\%20auto\%20industry/auto\%202030\%20report\%20 jan\%202016.ashx. Accessed 25. 9. 2019.

Markard, Jochen, Truffer, Bernhard. 2008. "Technological innovation systems and the multi-level perspective: Towards an integrated framework." Research policy 37 (4): 596-615.

Noordhoff, Corine S., Kyriakopoulos, Kyriakos, Moorman, Christine, Pauwels, Pieter, Dellaert, G. C. Benedict. 2011. "The bright side and dark side of embedded ties in business-to-business innovation." Journal of Marketing 75 (5): 34-52.

Oinas, Päivi, Malecki, J. Edward. 2002. "The evolution of technologies in time and space: from national and regional to spatial innovation systems." International regional science review 25 (1):102-131.

Oke, Adegoke, Prajogo, I. Daniel, Jayaram, Jayanth. 2013. "Strengthening the innovation chain: The role of internal innovation climate and strategic relationships with supply chain partners." Journal of Supply Chain Management 49 (4): 43-58.

Phirouzabadi, Amir Mirzadeh, Juniper, James Savage A. David, Blackmore, Karen. 2020. Supportive or inhibitive? - Analysis of dynamic interactions 
between the inter-organisational collaborations of vehicle powertrains. Journal of Cleaner Production, 244, 118790.

Pihlajamaa, Matti, Kaipia, Riikka, Aminoff, Anna, Tanskanen, Kari. 2019. "How to stimulate supplier innovation? Insights from a multiple case study." Journal of Purchasing and Supply Management. 25.

Potter, Antony, Graham, Stephanie. 2018. "Supplier involvement in ecoinnovation: The co-development of electric, hybrid and fuel cell technologies within the Japanese automotive industry." Journal of Cleaner Production: 210.

Rončević, Borut. 2019. "Cultural Political Economy of Europe 2020: Jean Monnet Chair CPE 2020 and its Impact". Research in Social Change 11 (2): 513.

Rutten, Roel, Boekema, Frans. 2007. "Spatial Innovation Systems: Theory and Cases - an Introduction." European Planning Studies 15 (2): 171-177.

Sloane, Alan D., Seamus, O’Reilly. 2013. “The emergence of supply network ecosystems: a social network analysis perspective." Production Planning \& Control: The Management of Operations 24 (7): 621-639.

Suurs, Roald A. A., Hekkert, P. Marko. 2009. "Cumulative causation in the formation of a technological innovation system: The case of biofuels in the Netherlands." Technological Forecasting and Social Change 76 (8): 10031020 .

Ter Wal, Anne L. J., Boschma, Ron. 2011. “Co-evolution of Firms, Industries and Networks in Space." Regional Studies 45 (7): 919-933.

Tingting, Yan, Dooley, J. Kevin, Choi, Y. Thomas. 2018. Measuring Supplier Innovation. Supply Chain Management Review-March/April 2018. https://www.scmr.com/article/measuring supplier innovation. Accessed 6. 9. 2020.

Turi, Attila, Mocan, Marian, Ivascu, Larisa, Goncalves, Gilles, Maistor, Sorin. 2015. From Fordism to Lean management: main shifts in automotive industry evolution within the last century. Joint international conference Managing Intellectual Capital and Innovation for Sustainable Society, 27.-29. May, Bari, 
Italy. http://www.toknowpress.net/ISBN/978-961-6914-130/papers/ML15-098.pdf. Accessed 25. 4. 2020.

Van Lancker, Jonas, Mondelaers, Koen, Wauters, Erwin, Van Huylenbroeck, Guido. 2016. "The Organizational Innovation System: A systemic framework for radical innovation at the organizational level." Technovation 52: 40-50.

Volgina, Natalia. 2011. "The automotive value chain in Russia: trends and perspectives." Societal Studies 3 (1): 123-138.

Wang, Jiajun. 2014. Evolution of Mega Supplier in Automotive Industry. https://dspace.mit.edu/bitstream/handle/1721.1/102136/2014_13_Wang. pdf;sequence=1. Accessed 29. 9. 2019.

Wieczorek, Anna J., Hekkert P. Marko, Coenen, Lars, Harmsen, Robert. 2015. Broadening the national focus in technological innovation system analysis: The case of offshore wind. Environmental Innovation and Societal Transitions, $14,128-148$.

Winkelhake, Uwe. 2018. The Digital Transformation of the Automotive Industry: Catalysts, Roadmap, Practice. Springer.

Winter, Stefan, Lasch, Rainer 2016. "Recommendations for supplier innovation evaluation from literature and practice." International Journal of Operations \& Production Management 36, 643-664. DOI: 10.1108/IJOPM-072014-0341.

Wittmann, Jochen. 2017. Electrification and Digitalization as Disruptive Trends: New Perspectives for the Automotive Industry? In: Phantom Ex Machina (pp.137-159). 


\section{Appendix}

Table 1: Sample of respondents and their innovation activity

\begin{tabular}{|c|c|c|c|c|c|c|c|c|c|}
\hline & & Num & r of & aten & & & & & \\
\hline $\begin{array}{l}\text { Respondent } \\
\text { no. }\end{array}$ & $\begin{array}{l}\text { Type of } \\
\text { respondent }\end{array}$ & $0-1$ & $\begin{array}{l}2- \\
3\end{array}$ & $\begin{array}{l}3- \\
10\end{array}$ & $\begin{array}{l}11- \\
20\end{array}$ & $\begin{array}{l}21- \\
50\end{array}$ & $\begin{array}{l}51- \\
100\end{array}$ & $\begin{array}{l}101- \\
200\end{array}$ & $\begin{array}{l}200 \\
\rightarrow\end{array}$ \\
\hline R1 & $\begin{array}{l}\text { Automotive } \\
\text { cluster }\end{array}$ & $\mathrm{X}$ & & & & & & & \\
\hline R2 & Large company & & & & & & & $\mathrm{X}$ & \\
\hline R3 & $\begin{array}{l}\text { Micro-enterprise } \\
\text { (spin-out) }\end{array}$ & $\mathrm{X}$ & & & & & & & \\
\hline $\mathrm{R} 4$ & $\begin{array}{l}\text { Technology } \\
\text { transfer office of } \\
\text { PRO }\end{array}$ & & & & & & & $\mathrm{X}$ & \\
\hline R5 & Large company & & & & & $\mathrm{X}$ & & & \\
\hline R6 & Large company & & $\mathrm{X}$ & & & & & & \\
\hline R7 & $\begin{array}{l}\text { Independent } \\
\text { inventor }\end{array}$ & & $\mathrm{X}$ & & & & & & \\
\hline R8 & Micro-enterprise & & & & $\mathrm{X}$ & & & & \\
\hline R9 & $\begin{array}{l}\text { Independent } \\
\text { inventor }\end{array}$ & & $\mathrm{X}$ & & & & & & \\
\hline $\mathrm{R} 10$ & Small enterprise & $\mathrm{X}$ & & & & & & & \\
\hline R11 & Large company & & & & & $\mathrm{X}$ & & & \\
\hline R12 & $\begin{array}{l}\text { Medium size } \\
\text { enterprise (spin- } \\
\text { out) }\end{array}$ & & & & $\mathrm{X}$ & & & & \\
\hline R13 & Micro-enterprise & & & $\mathrm{X}$ & & & & & \\
\hline R14 & Small enterprise & & & & & & $\mathrm{X}$ & & \\
\hline R15 & Micro-enterprise & & $\mathrm{X}$ & & & & & & \\
\hline R16 & Micro-enterprise & $\mathrm{X}$ & & & & & & & \\
\hline R17 (AT) & Large company & & & & & & & & $\mathrm{X}$ \\
\hline R18 (AT) & Small enterprise & $\mathrm{X}$ & & & & & & & \\
\hline R19 (HU) & $\begin{array}{l}\text { Medium-sized } \\
\text { enterprise }\end{array}$ & & & $\mathrm{X}$ & & & & & \\
\hline R20 (HU) & $\begin{array}{l}\text { Automotive } \\
\text { cluster }\end{array}$ & $\mathrm{X}$ & & & & & & & \\
\hline
\end{tabular}

